\title{
REKONSTRUKSI PEMBELAJARAN BAHASA ARAB
}

\author{
Nawang Wulandari \\ Institut Agama Islam Negeri (IAIN) Metro \\ Jl. Ki Hajar Dewantara, Iringmulyo, Metro Timur, Metro, Lampung 34381 \\ e-mail: darinawangwulan@gmail.com
}

\begin{abstract}
This study aims to reformulate (reconstruct) of Arabic learning. The research site chosen is IAIN Metro Lampung. This university is one of Islamic Universities in Indonesia that requires the students to learn and master Arabic. This study formulate steps that are tailored to the characteristics of student in IAIN Metro, especially for students who are not studying at Arabic language education. After the data has been analyzed and reviewed, the conclusion of the formulation of the reconstruction of Arabic learning is to reformulate the general and specific instructional objectives, to reformulate teaching materials, learning strategies and assessment strategies.
\end{abstract}

Key Word: Reconstruction, Arabic Learning, Islamic University

\begin{abstract}
Abstrak
Tulisan ini membahas upaya perumusan ulang (rekonstruksi) pembelajaran bahasa bagi mahasiswa non PBA di IAIN Metro. Pada penelitian ini dirumuskan langkah-langkah merekonstruksi pembelajaran bahasa Arab dasar yang sesuai dengan heterogenitas karakteristik mahasiswa di IAIN Metro serta disesuaikan dengan profil lulusan masing-masing jurusan. Setelah data dianalisa dan dikaji, diperoleh kesimpulan rumusan rekonstruksi pembelajaran bahasa Arab di antaranya adalah merumuskan kembali tujuan instruksional umum dan khusus, merumuskan kembali materi ajar, strategi pembelajaran dan strategi penilaian.
\end{abstract}

Kata Kunci: Rekonstruksi Pembelajaran, Bahasa Arab, Universitas Islam 


\section{A. Pendahuluan}

Salah satu ciri khas pembelajaran pada Perguruan Tinggi Keagamaan Islam Negeri (PTKIN) di Indonesia adalah adanya mata kuliah keislaman yang harus ditempuh oleh seluruh mahasiswanya, salah satunya adalah mata kuliah bahasa Arab. Beberapa mata kuliah keislaman tersebut bertujuan untuk penanaman dan pengamalan nilai-nilai keislaman pada mahasiswa.

Adanya mata kuliah bahasa Arab ini merupakan upaya pengenalan dan peningkatan kompetensi bahasa asing. Jauh daripada itu adalah karena sumber-sumber asli hukum Islam termaktub dalam bahasa Arab. Namun kendala yang muncul dalam pembelajaran bahasa Arab, khususnya pada jurusan non Pendidikan bahasa Arab (PBA) di IAIN Metro di antaranya adalah sulitnya mencapai tujuan pembelajaran yang telah ditetapkan pada silabus. Hal ini karena tidak semua mahasiswa di IAIN Metro pernah belajar bahasa Arab, sebagian mahasiswa baru di IAIN Metro merupakan lulusan sekolah umum, sebagian mereka banyak yang kesulitan menulis dan membaca tulisan Arab.

Materi-materi yang disajikan pada silabus mata kuliah bahasa Arab untuk mahasiswa non PBA juga cenderung "tinggi” bagi pembelajar pemula. Hal tersebut diaminkan oleh para dosen pengampu mata kuliah bahasa Arab di jurusan non PBA seperti jurusan Tadris IPS, Tadris Biologi, Tadris Bahasa Inggris, Ekonomi Syariah, Akuntansi Syariah, Hukum Keluarga Islam dan lainnya. Materi-materinya juga masih bersifat umum, tema-temanya belum disesuaikan dengan profil lulusan masing-masing jurusan di IAIN Metro. Sikap yang akhirnya diambil oleh dosen-dosen bahasa Arab adalah dengan membuat materi sendiri yang disesuaikan dengan heterogenitas mahasiswa.

Permasalahan heterogenitas karakteristik mahasiswa juga akhirnya membutuhkan perhatian khusus. Perlu dilakukan pembaharuan kurikulum pembelajaran bahasa Arab, agar sesuai dengan perkembangan zaman. Selain standar kurikulum pembelajaran bahasa Arab saat harus mempertimbangkan 
berbagai faktor dan variabel terkait dengan filsafat bahasa, aspek sosial budaya, psikologi mahasiswa yang belajar bahasa, lingkungan sosial politik, sistem pendidikan dan pembelajaran, sumber daya manusia (input mahasiswa maupun tenaga pendidik) dan lain sebagainya. ${ }^{1}$ Mestinya sudah mulai dipetakpetakkan pembelajaran bahasa Arab sesuai dengan profil lulusan, sehingga akan ada mata Kuliah Bahasa Arab untuk Jurusan Biologi, Bahasa Arab untuk Akuntansi Syariah dan sebagainya. Dengan demikian harapan pembelajaran bahasa Arab yang lebih baik dapat terwujud. Sebab kualitas pendidikan tidak hanya dilihat dari sekadar penyelenggaraan pendidikan, tetapi pendidikan yang bermutu, baik dari sisi input, proses, dan output, maupun outcome. ${ }^{2}$

Kurikulum harus relevan dengan tujuan pendidikan yang hendak dicapai, karena merupakan sarana pencapaian tujuan-tujuan pendidikan. Begitu juga dengan pembelajaran bahasa Arab, selain menjadikan bahasa Arab sebagai objek kajiannya juga mempelajari bagaimana cara mengajarkannya. Tujuan ini akan lebih mudah terwujud jika seluruh komponen kurikulum pendidikan bahasa Arab bersatu dan relevan dengan tujuan tersebut. ${ }^{3}$

\section{B. Landasan Teori}

\section{a. Karakteristik Peserta Didik (Mahasiswa)}

Mahasiswa IAIN Metro terdiri dari latar belakang yang beragam. Jika dilihat dari latar belakang pendidikannya, maka dapat dikategorikan menjadi dua kategori, yang pertama yaitu

${ }^{1}$ Abdul Wahab Muhbib, "Standarisasi Kompetensi Bahasa Arab bagi Calon Sarjana Keguruan Tinggi Keagamaan Islam Negeri," Jurnal Arabiyat Vol. 5 No. 1, (Juni 2018), http://dx.doi.org/10.15408/a.v5i1.6691.

2 Tim Dosen Administrasi Pendidikan UPI, Manajemen Pendidikan (Bandung: Alfabeta, 2009), h. 288.

${ }^{3}$ Novita Rahmi, "Relevansi Kurikulum Dan Wujud Kongkret Tujuan Pembelajaran Bahasa Arab," An Nabighoh: Jurnal Pendidikan Dan Pembelajaran Bahasa Arab 19, no. 1 (30 Juli 2017): 107-26, https://doi.org/10.32332/an-nabighoh.v19i1.760. 
mahasiswa yang berasal dari sekolah keagamaan, seperti pondok pesantren dan madrasah aliyah dan yang kedua, mahasiswa yang berasal dari sekolah umum.

Perbedaan latar belakang pendidikan itu menyebabkan adanya kesenjangan dalam pembelajaran bahasa Arab dalam satu kelas. Misalnya bagi mahasiswa yang berasal dari pondok pesantren merasa bosan dengan materi yang diberikan di kelas, karena materi yang diajarkan sudah dikuasai. Berbeda dengan mahasiswa yang belum pernah belajar bahasa Arab sebelumnya, mereka butuh konsentrasi ekstra dan pengulangan latihan-latihan untuk dapat mencapai tujuan pembelajaran yang diinginkan.

Selain dari latar belakang pendidikan, hal lainnya juga menjadi perhatian yaitu kondisi ekonomi orangtua mereka. Sebagian besar mahasiswa IAIN Metro berasal dari masyarakat kelas menengah ke bawah dan merupakan anak-anak dari daerah. Banyak di antara mereka yang membutuhkan bantuan biaya kuliah dalam bentuk beasiswa. Bahkan ada mahasiswa yang kuliah sambil bekerja, sehingga waktu pulang kuliah yang seharusnya dapat dipakai untuk istirahat dan mengulang lagi pelajaran dipakai untuk bekerja. Berbagai kondisi itu berpengaruh pada kesiapan mahasiswa untuk mempersiapkan atau membeli sarana pembelajaran misalnya buku dan kamus bahasa Arab.

\section{b. Tujuan Pembelajaran Bahasa Arab}

Pembelajaran secara sederhana dapat diartikan sebagai sebuah usaha mempengaruhi emosi, intelektual, dan spiritual seseorang agar mau belajar dengan kehendaknya sendiri. Melalui pembelajaran akan terjadi proses pengembangan moral keagamaan, aktivitas, dan kreativitas mahasiswa melalui 
berbagai interaksi dan pengalaman belajar. Pembelajaran berbeda dengan mengajar yang pada prinsipnya menggambarkan aktivitas pengajar, sedangkan pembelajaran menggambarkan aktivitas mahasiswa. ${ }^{4}$

Tujuan pembelajaran bahasa Arab adalah mengembangkan kemampuan peserta didik dalam berbahasa Arab, baik secara lisan maupun tulisan. ${ }^{5}$ Tujuan pembelajaran bahasa Arab diarahkan kepada tida hal. Pertama, penguasaan unsur bahasa yang dimiliki bahasa Arab, yaitu: unsur bunyi, kosa kata, ungkapan, dan struktur. Kedua, penggunaan bahasa Arab dalam komunikasi yang efektif. Dan ketiga sebagai pemahaman terhadap budaya Arab, baik berupa pemikiran, nilai-nilai, adat, etika maupun seni. ${ }^{6}$

\section{Metode Penelitian}

Penelitian ini adalah penelitian lapangan (field research), yaitu penelitian yang menjadikan data lapangan sebagai sumber data utamanya yang bertujuan untuk menemukan, mengembangkan, dan menguji suatu ilmu pengetahuan. Desain penelitian ini adalah penelitian kualitatif-deskriptif, yaitu sebuah penelitian yang berusaha mengungkap keadaan yang bersifat alamiah secara holistik. Penelitian kualitatif bukan hanya menggambarkan variabel-variabel tunggal melainkan dapat mengungkap hubungan antara satu variabel dengan variabel lain. ${ }^{7}$

\footnotetext{
2009), h. 85.

5 Sulastri, "Pengembangan Media Pembelajaran Arabic Thematic Video Pada Keterampilan Berbicara Siswa Kelas VIII MTS," Jurnal Lisanul Arab Vol 5 No 1 (2016): 22.

${ }^{6}$ Ahmad Muradi, "Pengembangan Kompetensi Guru Bahasa Arab melalui IMLA sebagai Organisasi Profesi," Jurnal Arabi Vol 1 No 2 (2016): 8.

7 M. Sayuthi Ali, Metodologi Penelitian Agama; Pendekatan Teori dan Praktek (Jakarta: PT RajaGrafindo Persada, 2002).
}

${ }^{4}$ Abuddin Nata, Perspektif Islam tentang Strategi Pembelajaran (Jakarta: Kencana, 
Sumber data dalam penelitian ini dikategorikan dalam dua kelompok besar: Pertama, sumber data primer, yaitu data yang diperoleh secara langsung dari subyek penelitian. Untuk memperoleh data ini, peneliti akan melakukan wawancara (interview) dengan beberapa informan yaitu para dosen pengampu mata kuliah bahasa Arab dan Mahasiswa di IAIN Metro.

Kedua, sumber data sekunder, yaitu diperoleh dengan melakukan studi literatur dan studi dokumen. Dalam penelitian ini, literatur yang digunakan adalah buku, jurnal, artikel dan majalah baik cetak maupun elektronik yang terkait dengan penelitian ini, yaitu tentang rekontruksi pembelajaran bahasa Arab (Sebuah Upaya Merumuskan Pembelajaran Bahasa Arab Berdasarkan Hetrogenitas Karakteristik Mahasiswa Pada Jurusan Selain Pendidikan Bahasa Arab).

Populasi dalam penelitian adalah keseluruhan obyek penelitian, baik berupa orang, peristiwa atau gejala yang ditetapkan oleh peneliti, untuk dipelajari dan ditarik kesimpulan. Populasi penelitian ini adalah dosen mata kuliah bahasa Arab dan Mahasiswa di IAIN Metro.

Teknik sampling yang digunakan dalam penelitian ini adalah teknik purposif sampling, yaitu teknik mengambil sampel berdasarkan ciri-ciri populasi yang telah diketahui sebelumnya. Dalam penelitian ini menunjuk anggota populasi dengan dasar keyakinan bahwa anggota tertentu inilah yang paling tepat untuk dijadikan sampel dalam menggali informasi yang valid.

Dalam melakukan proses pengumpulan data, peneliti akan menggunakan beberapa teknik; pertama, wawancara semi terstruktur yaitu metode interview yang dilakukan oleh interviewer dengan menanyakan serentetan pertanyaan yang sudah terstruktur dan tertata, kemudian satu-persatu diperdalam dalam mengorek keterangan lebih lanjut. ${ }^{8}$ Dan wawancara mendalam (dept

8 Suharsimi Arikunto, Prosedur Penelitian Suatu Pendekatan Praktik (Bandung: Rineka Cipta, 1993), h. 197. 
interview), yaitu metode yang digunakan untuk memperoleh informasi yang akurat berkaitan dengan masalah yang diteliti. ${ }^{9}$ Kedua, dokumentasi, dokumentasi digunakan untuk memperoleh data sekunder, yakni dengan mengumpulkan dokumen-dokumen dan literatur yang memiliki relevansi dengan penelitian ini, ketiga, observasi, observasi atau pengamatan merupakan suatu teknik atau cara mengumpulkan data dengan jalan mengadakan pengamatan terhadap kegiatan yang sedang berlangsung. Dengan observasi, peneliti akan mengetahui keadaan di lapangan untuk menganalisis kebutuhan dan karakteristik mahasiswa di IAIN Metro.

Analisis data dilakukan dengan menggunakan langkah-langkah sebagai berikut: Pertama, pengumpulan data, yaitu kegiatan untuk menemukan dan menghimpun sumber-sumber informasi yang relevan dengan penelitian. Kedua, interpretasi data, yaitu tahap penyusunan fakta dalam kerangka logis dan harmonis, sehingga menjadi kesatuan yang utuh. Kegiatan penyusunan ini disebut juga dengan proses sintesis atau interpretasi. Ketiga, penulisan, yaitu tahap ketika hasil interpretasi ditulis secara sistematis, logis, harmonis, dan konsisten, baik dari segi kata maupun alur pembahasan. Secara teoretik, analisis data adalah proses menyusun, mengkategori, mencari pola atau tema dari data yang ada dengan maksud untuk memahami maknanya. ${ }^{10}$

Dalam penelitian kualitatif ini, terdapat tiga komponen pokok yang akan dilalui peneliti, yaitu data reduction, data display, dan conclusion drawing. ${ }^{11}$ Tiga komponen analisis ini berlaku saling menjamin, baik sebelum, pada waktu, dan sesudah pelaksanaan pengumpulan data secara paralel. Analisis ini pada umumnya disebut model analisis mengalir (flow model of analysis).

\footnotetext{
9 Koentjaraningrat, "Metode Wawancara" dalam Koentjaraningrat, ed., Metode Penelitian Masyarakat (Jakarta: Gramedia, 1991), h. 138-140. h. $4-8$.

${ }^{10}$ Lexy J. Moleong, Metodologi Penelitian Kualitatif (Bandung: Remaja Karya, 1989),

11 Heribertus Sutopo, Pengantar Penelitian Kualitatif: Dasar-Dasar Teoritis dan Praktis (Surakarta: Puslit UMS, 1988), h. 34.
} 


\section{Pembahasan}

\section{a. Pembelajaran Bahasa Arab di IAIN Metro}

Pembelajaran bahasa Arab bagi mahasiswa non PBA di IAIN Metro terdiri dari mata kuliah bahasa Arab 1 yang diprogramkan pada semester ganjil dan bahasa Arab 2 yang diprogramkan pada semester genap.

Tujuan pembelajaran bahasa Arab bagi mahasiswa pada jurusan selain pendidikan bahasa Arab di IAIN Metro ini sejalan dengan tujuan umum pembelajaran bahasa Arab yang dirumuskan oleh Kemenag, bahwa tujuan umum pembelajaran bahasa Arab adalah: 1) untuk dapat memahami al-Quran dan hadist sebagai sumber hukum ajaran Islam; 2) untuk dapat memahami buku-buku agama dan kebudayaan Islam yang ditulis dalam bahasa Arab; 3) untuk dapat berbicara dan mengarang dalam bahasa Arab; 4) untuk dapat digunakan sebagai alat pembantu keahlian lain (supplementary); 5) untuk membina ahli bahasa arab, yakni benar-benar professional.

Tujuan pembelajaran bahasa Arab ini terkesan masih bersifat sangat luas, belum ada kesepakatan antara para dosen mengenai arah keterampilan yang ingin dicapai, apakah itu keterampilan berbicara (Maharah kalam), menyimak (maharah Istima'), menulis (maharah kitabah), atau mambaca (maharah qiroah). Setiap dosen mengajar sesuai keterampilan yang diinginkan oleh masing-masing dosen, sehingga antara satu jurusan dengan jurusan lainnya tidak sama arah dan orientasi keterampilan yang ingin dicapai.

\section{b. Materi Pembelajaran Bahasa Arab Dasar di IAIN Metro}

Mata kuliah bahasa Arab termasuk mata kuliah institut dan mata kuliah wajib di semua fakultas dan jurusan. Materi Perkuliahan Bahasa Arab untuk tiap jurusan hampir semuanya sama karena materinya 
dimulai dari dasar meskipun disusun oleh masing-masing dosen pengampu matakuliah bahasa Arab pada jurusan.

Standar kompetensi pada mata kuliah bahasa Arab 1 adalah mahasiswa memiliki kemampuan untuk menjelaskan konsepsi kata benda (isim), kata kerja (fi'il) dan huruf dalam bahasa Arab. Materimateri pokok yang diajarkan adalah $\mathrm{Al}$ Kalimah wa Anwauha, Taqsim Al ism ilal Mufrad wal Mutsana wal Jama', Muannats dan Mudzakar, Ismul Isyarah, Anwa' Al fi'ill (Madhi, Mudhari' wal Amr), Tashrif Al Af'al, Anwa Al Jumlah (Jumlah Ismiyah wa Jumlah filiyah) dan Al Mubtada' wal khabar.

Sedangkan untuk mata kuliah bahasa Arab 2, standar kompetensi yang ditetapkan adalah mahasiswa memiliki kemampuan untuk memahami aspek -aspek bahasa Arab sampai menjadi struktur secara sederhana. Materi pokok yang diajarkan yaitu Al-Istifham, AsShifat wal Maushuf, Harful Jar, Taqdim al Maf'ul 'alal Fa'il, Al Idhafah, Al Nisbah, Al 'Adad wal ma'dud, Kaana wa Akhwatuha, Inna wa Akhwatuhaa, Ilmu Ma'ani, Ilmu Bayan dan Ilmu Badi'.

Dari pokok-pokok materi yang ditetapkan di atas, bisa dipahami jika penyusun silabus masih menganut paradigma lama pembelajaran bahasa Arab, bahwa untuk menguasai bahasa Arab harus dimulai dari pengenalan kaidah. Hal ini tidak sepenuhnya salah, namun rentan menimbulkan kejenuhan mahasiswa dalam belajar bahasa Arab. Akan lebih tepat dan menyenangkan jika tujuan pembelajaran bahasa Arab dasar ini langsung disesuaikan dengan profil lulusan yang hendak dicapai oleh masing-masing jurusan. Sehingga materi yang ditetapkan juga disesuaikan dengan masing-masing jurusan dan keterampilan bahasa yang hendak dikuasai dapat lebih terarah. Materi tersebut diajarkan dengan metode ceramah, diskusi dan Tanya jawab. 
Merujuk pada silabus mata kuliah bahasa Arab di IAIN Metro, dilihat dari materi yang diberikan, tujuan pembelajaran bahasa Arab di IAIN Metro bukan mengajarkan keterampilan berbahasa, namun teori bahasa Arab. Jika melihat dari tujuan intruksional khusus, maka tugas dosen yaitu berusaha keras agar siswa menjadi mampu berbahasa dengan bahasa yang dipelajarinya. Jadi tugas dosen sebagai seorang pengajar yaitu mengajarkan bahasa, bukan mengajarkan teori bahasa. ${ }^{12}$

Setiap masing-masing jurusan harusnya menetapkan keterampilan berbahasa apa yang hendak dicapai, apakah itu keterampilan berbicara (Maharah kalam), menyimak (maharah Istima'), menulis (maharah kitabah), atau mambaca (maharah qiroah). Sehingga nantinya kurikulum dan silabus pembelajaran bahasa Arab dapat dikontruks sesuai dengan kebutuhan dan relevansi keilmuan masing-masing fakultas atau jurusan. Misalnya untuk jurusan KPI mungkin bisa lebih cenderung pada keterampilan berbicara (maharah kalam) karena profil lulusan jurusan KPI diantaranya adalah sebagai Da'I (mubaligh), Public Relation, Penyuluh agama dan lainnya. Sehingga pokok-pokok materi yang diajarkan hendaknya lebih sering menekankan pada muahadtsah dengan tema boardcasting ataupun pengenalan kosa kata yang berkaitan dengan penyiaran, media, Radio, film dan lain-lain dengan menggunakan metode pembelajaran yang sesuai dan tepat.

\section{c. Rekontruksi Pembelajaran Bahasa Arab di IAIN Metro}

Agar tujuan pembelajaran bahasa Arab dapat dicapai secara maksimal sesuai dengan hetrogenitas karakteristik mahasiswa di IAIN Metro, maka perlu dilakukan rekontruksi atau pengkajian ulang

\footnotetext{
${ }^{12}$ Shafruddin Tajuddin, "Pengembangan Model Pembelajaran Bahasa Arab Tingkat Sekolah Dasar untuk Meningkatkan Kemampuan Berbahasa Arab Siswa," Parameter: Jurnal Pendidikan Universitas Negeri Jakarta 29, no. 2 (21 Juni 2017): 200-215, https://doi.org/10.21009/parameter.292.08.
} 
terhadap terhadap kurikulum. Mengkaji ulang kurikulum menjadi poin penting dalam merekontruksi pembelajaran bahasa Arab bagi mahasiswa pada jurusan selain pendidikan bahasa Arab.

Sebelum melakukan rekontruksi pembelajaran bahasa Arab, perlu dilakukan evaluasi program pembelajaran. Dalam proses evaluasi ini ada beberapa point yang penting untuk diperhatikan, diantaranya adalah apakah tujuan intruksional umum mata kuliah ini relevan dengan kompetensi kebutuhan lulusan? Apakah daya serap mahasiswa menjadi kendala? Apakah motivasi belajar siswa cukup memadai? Apakah literature mutakhir tersedia di perpustakaan? Apakah jumlah alokasi waktu setara dengan bobot sks? Apakah evaluasi belajar identik dengan TIK yang dirumuskan? Dan lain-lain.

Selanjutnya, setelah memperhatikan point di atas, hal yang kemudian dilakukan agar mata kuliah bahasa Arab dasar 1 dan 2 sesuai dengan hetrogenitas karakteristik mahasiswa adalah dengan tahaptahap berikut ini:

\section{Merumuskan Kembali Tujuan Intrusional Pembelajaran}

Tujuan intruksional di sini merupakan target yang akan dicapai setelah mempelajari bahaasa Arab, yaitu berupa kompetensi kemahiran bahasa. Standarisasi kompetensi bahasa Arab baiknya mencangkup tentang empat penguasaan keterampilan bahasa, yaitu maharah istima' (keterampilan mendengar), maharah kalam (keterampilan berbicara), maharah qiraah (keterampilan membaca) dan maharah kitabah (Keterampilan menulis).

Namun jika keempat keterampilan di atas tidak dapat dicapai karena keterbatasan waktu dan standar input yang rendah, maka dapat talngsung melihat kepada profil lulusan masing-masing jurusan. Keterampilan yang dinilai relevan dan sesuai dengan visi 
misi institusi dan profil lulusan mahasiswa adalah keterampilan berbicara, keterampilan berbicara (maharah kalam) adalah keterampilan mengungkapkan ide, pendapat, keinginan atau gagasan melalui lisan sehingga terbentuk bunyi-bunyi atau katakata yang dapat dimengerti. Keterampilan utama dalam pengajaran bahasa, para pendidik sepakat jika 95\% aktivitas bahasa merupakan kegiatan lisan. ${ }^{13}$ Namun harus disesuaikan dengan pengelompokan dan peminatan jurusan-jurusan yang ada di IAIN Metro. Ada kecenderungan kuat bahwa kompetensi membaca teks Arab disesuaikan dengan jurusan, karena dapat mendorong dan menunjang peningkatan kompetensi profesional calon lulusanya.

Dalam memetakan tujuan intruksioanal pembelajaran bahasa Arab, pemegang kebijakan dan dosen-dosen bahasa Arab harus “duduk bersama' untuk menyamakan persepsi. Masing-masing jurusan harus memetakan ke arah keterampilan bahasa apa yang ingin dikuasai, apakah keterampilan berbicara (Maharah kalam), keterampilan menyimak (maharah Istima'), keterampilan menulis (maharah kitabah), atau keterampilan mambaca (maharah qiroah).

Bapak Khoirurrijal menyatakan bahwa maharah yang harus dikuasai oleh mahasiswa IAIN Metro yang non PBA adalah maharah qiroah (keterampilan membaca) dan maharah kitabah (keterampilan menulis) sebab kalau mahasiswa salah bacaannya, dapat salah juga artinya. Jadi mahasiswa harus menguasai maharah qiroah dan kitabah. ${ }^{14}$

${ }^{13}$ Muhammad Sholahuddin Mujawar, Tadris Al Lughah Al Arabiyah bil Marhalah Al Ibtidaiyah (Kuwait: Dar Al Qolam, 1980), h. 190.

${ }^{14}$ Hasil wawancara kepada Dr. Khoirurrijal, Dosen Bahasa Arab IAIN Metro. 
Menurut hemat penulis, kompetensi dan keterampilan bahasa Arab yang lebih diprioritaskan untuk jurusan-jurusan non PBA di IAIN Metro ini adalah keterampilan membaca, meskipun ada pula yang menghendaki mahasiswa mampu berkomunikasi lisan dan tulisan dalam bahasa Arab secara memadai. Pandangan ini didasarkan bahwa keterampilan membaca merupakan kunci untuk dapat mengakses dan memahami sumber hukum islam yaitu al quran dan hadits dan memahami teks-teks keislaman yang berbahasa Arab. Selain keterampilan membaca, pada jurusan KPI keterampilan bahasa yang juga harus dikuasai adalah keterampilan berbicara (maharah kalam) karena profil lulusan jurusan KPI diantaranya adalah sebagai Da'I (mubaligh), Public Relation, Penyuluh agama yang memang lebih menekankan kemampuan beretorika.

Pendapat yang sama juga disampaikan oleh Bapak Jono Sutarjo, "Kalau untuk jurusan-jurusan lain yang non PBA saya rasa keterampilan bahasa yang pas dan penting bagi mereka adalah Maharah Qiroah (keterampilan membaca), apalagi untuk mahasiswa yang di jurusan Syariah, mereka kan harus bisa membaca kitab kuning"

Jika tujuan intruksionalnya adalah agar mahasiswa menguasai maharah qiroah (keterampilan berbicara), maka standar kompetensi membaca yang harus dimiliki oleh mahasiswa, setelah belajar satuan pembelajaran bahasa Arab mahasisw mampu:

a. Melafalkan materi teks Arab dengan makharijul huruh yang tepat

b. Membaca materi teks Arab menggunakan nahwu dan sharaf dengan tepat. 
c. Merumuskan ide utama (ide pokok) pada materi atau teks Arab yang dibaca

d. Menjelaskan informasi dari teks Arab yang dibaca

e. Menyimpulkan isi teks Arab yang dibaca

f. Menerjemahkan tek Arab yang dibaca

Sebagai penunjang untuk menguasai kompetensi di atas, maka ada beberapa kompetensi pendukung yang juga harus dikuasai mahasiswa, diantaranya adalah menguasai kosakata pada jumlah tertentu dalam setiap satuan pembelajaran, mampu mengenal ungkapan-ungkapan komunikatif, serta mampu mengaplilasikan struktur dasar kalimat berbahasa Arab.

\section{Menyusun Kembali Materi-materi Ajar Bahasa Arab}

Setelah merumuskan tujuan intruksional pembelajaran bahasa Arab, lebih lanjut ditetapkan materi-materi yang akan diajarkan. Penyusunan materi-materi ajar bahasa Arab baiknya disesuaikan dengan profil lulusan pada masing-masing jurusan, agar menunjang peningkatan kompetensi profesional calon lulusanya.

Materi-materi yang ada pada silabus pembelajaran bahasa Arab 1 dinilai masih relevan untuk digunakan pada jurusan-jurusan selain pendidikan bahasa Arab di IAIN Metro. Sedangkan untuk mata kuliah bahasa Arab 2, materi-materi yang diberikan baiknya diesesuaikan dengan fakultas dan jurusan masing-masing.

Misalnya pembelajaran bahasa Arab bagi mahasiswa fakultas syariah yang memang harus lebih meneknkan pada keterampilan membaca (maharah qiroah), dengan tujuan, agar mahasiswa dapat memahami sumber-sumber asli hukum Islam yaitu Al Quran, hadits dan ilmu-ilmu keislaman yang tertulis dalam bahasa Arab. Karena mahasiswa lulusan jurusan ini akan menjadi praktisi hukum Islam. 
Maka materi-materi yang ditetapkan untuk mahasiswafakultas syariah berupa teks-teks berbahasa Arab dengan tema-tema hukum dan ketata negaraan, percakapan dan menghafal mufrodat yang berhubungan dengan hukum islam. Hal ini dimaksudkan pula setelah lulus mata kuliah bahasa Arab, mahasiswa memiliki modal awal untuk mengikuti mata kuliah membahas kitab pada semester selanjutnya.

Begitu juga dengan mahasiswa di fakultas Ekonomi dan Bisnis Islam (FEBI), dengan profil lulusannya sebagai analis ekonomi syariah, praktisi lembaga keuangan dan ZISWAF, konsultan bisnis di lembaga keuangan syariah, dewan pengawas keuangan yariah, maka materi-materi bahasa arab yang harus diberikan adalah hiwar tentang kegiatan-kegiatan di Bank, menghafal kosa kata seputar bank, BMT dan lain-lain. Perlu juga diajarkan cara melafalkan istilah-istilah BMT dalam bahasa Arab, agar tidak ada lagi mahasiswa yang salah melafalkan kata mudharabah, musyarakah, dll.

Pada jurusan jurusan yang lain juga diseragamkan, yang membedakan hanya tema-tema materinya saja, jika di fakultas ekonomi temanya lebih berputat tentang bank, atau menguasai kosa kata tentang istilah-istilah perbankan dalam bahasa Arab, begitu juga untuk mahasiswa jurusan pendidikan, dapat diberikan hiwar ataupun bacaan yang berkaitan dengan tema-tema pendidikan. Sedangkan untuk jurusan KPI, karena profil lulusannya adalah sebagai Da'I (mubaligh), Public Relation, dan praktisi lainnya yang menekankan pada kemampuan berbicara, maka kompetensi kebahasaan yang juga perlu dikuasai adalah maharah kalam (keterampilan berbicara). Materi dalam keterampilan berbicara ini 
dapat berupa hiwar dengan tema tema yang sesuai dengan jurusan KPI, misalnya dengan tema radio, media masa, dan lain sebagainya. Mengingat bahwa fungsi utama bahasa adalah komunikatif, maka materi-materi dan pendekatan dalam pengajarannya hendaknya berupa materi yang praktik dan pragmatis, yaitu materi ajar yang dapat dikomunikasikan oleh mahasiswa secara lisa maupun tulisan. $^{15}$

\section{Menyusun Kembali Strategi Intruksional}

Hasil wawancara dengan dosen pengajar bahasa arab pada jurusan non PBA menyatakan bebrapa masalah yang muncul dalam pembelajaran bahasa Arab ini diakibatkan dari kemampuan awal bahasa Arab mahasiswa yang berbeda-beda, keragaman persepsi mahasiswa, motivasi belajar yang rendah, kurang gigih, dan malas membaca serta mengulang pelajaran di rumah.

Dari hasil wawancara kepada mahasiswa, ditemukan fakta adanya mahasiswa yang hampir tiga kelas mendapat nilai $\mathrm{C}$ untuk mata kuliah bahasa Arab. Dari tiga kelas tersebut hanya sebagian kecil saja yang lulus. Para mahasiswa yang mendapat nilai $\mathrm{C}$ tersebut menyatakan bahawa mereka sudah mengikuti tata tertib yang ditetapkan dalam kontrak kuliah; memenuhi 80\% kehadiran, mengerjakan tugas-tugas yang diberikan dosen, mengikuti UTS dan UAS.

Peneliti selanjutnya melakukan wawancara terhadap dosen yang mengajar bahasa Arab tersebut di atas. Dari hasil wawancara didapat pernyataan dosen yang cukup simple, "karena memang mahasiswa belum mampu mencapai standard yang diinginkan”.

${ }^{15}$ Baiq Tuhfah, "Pembelajaran Bahasa Arab Melalui Pendekatan Komunikatif" Vol 4, No 1 (Juni 2016): 59. 
Menurut hemat penulis, pada kahasus ini masalah yang muncul tidak hanya dari mahasiswa, namun dari dosen sendiri sebagai penyampai materi, mungkin dapat dilakukan dengan mengupgrade metode-metode mengajar perlu dilakukan rapat khusus penyamaan persepsi sesame dosen pengajar bahasa Arab untuk jurusan non PBA.

Dari berbagai permasalahan yang timbul tersebut, utuk mengoptimalkan pembelajaran bahasa Arab yang sesuai dengan hetrogenitas karakteristik mahasiswa dapat dilakukan strategi intruksional sebagi berikut:

a. Melakukan pre test sebagai upaya memetakan kemampuan awal mahasiswa

b. Membagi mahasiswa dalam beberapa kelompok kecil dengan tingkat kemampuan yang beragam, dipimpin oleh mahasiswa yang dinilai lebih pintar sehingga dapat terjadi interaksi positif san dapat memecahkan masalah bersama-sama.

c. Membertugas resume setiap materi yang diajarkan dengan menentukan pustaka-pustaka acuan. Hal ini juga sebagai upaya mendongkrak semangat baca mahasiswa.

d. Penilaian berbasis individu, meskipun pada tugas-tugas yang dikerjakan secara kelompok. Hal ini diharapkan dapat memotivasi mahasiswa untuk lebih mandiri dan bertanggungjawab terhadap diri sendiri.

\section{Menyusun Strategi Penilaian dan Hasil Belajar}

Strategi penilaian di sini menyangkut evaluasi pembelajaran bahasa Arab, yaitu kegiatan yang dilaksanakan untuk mengetahui apakah tujuan yang telah ditetapkan tercapai atau tidak. jika merujuk pada tujuan intruksional di atas, bahwa maharah qiroah 
(keterampilan membaca) yang ingin dikuasi, maka bentuk penilaiannya (tesnya) juga harus disesuaikan.

Sasaran utama tes kemampuan membaca sama dengan tujuan pokok membaca itu sendiri, yaitu kemampuan dalam memahami isi bacaan. ${ }^{16}$ Dalam keterampilan membaca sendiri terbagi menjadi 2, yaitu membaca keras dan membaca pemahaman, atau da yang menyebutnya membaca dalam hati.

Pada tes kemampuan membaca pemahaman (fahmul maqru,) dimaksudkan untuk mengukur tingkat kemampuan kognitif mahasiswa dalam memahami wacana tulis. Jabaran oprasional dari "memahami" itu sendiri masih bervariasi sesuai dengan tingkat kemampuan mahasiswa. Misalnya kemampuan menemukan informasi tersurat maupun tersirat dalam suatu wacana tulis, menentukan ide pokok dalam suatu paragraph, menentukan hubungan antar paragraph, menyimpulkan isi wacana, dan menentukan tema atau judul bacaan.

Sedangkan dalam membaca keras (membaca teknis) indicator kompetensi yang harus diperhatikan dalam menilai meliputi: ketepatan bacaan, kelancaran, intonasi dan kefasihan. Tes membaca yang diberikan pada mahasiswa pemula, sebaiknya terdiri dari satu atau dua kalimat sederhana, tidak sampai satu atau dua paragraph. Sementara bagi mahasiswa tingkat lanjut, dapat diberi bacaan yang agak panjang, namun tetap disesuaikan dengan alokasi waktu yang tersedia.

${ }^{16}$ M. Soenardi Djiwandono, Tes Bahasa dalam Pengajaran (Bandung: ITB, 1996). 


\section{E. Simpulan}

Berdasarkan data hasil penelitian dan pembahasan dapat disimpulkan bahwa rumusan rekonstruksi pembelajaran bahasa Arab yang sesuai dengan heterogenitas karakter mahasiswa non PBA adalah dengan meninjau ulang kurikulum pembelajaran bahasa Arab melalui langkah-langkah berikut ini: 1). Merumuskan kembali tujuan instruksional pembelajaran bahasa Arab. Merujuk pada profil lulusan di beberapa jurusan selain pendidikan bahasa Arab (PBA), dari keempat keterampilan berbahasa Arab yang harus dkuasai, tujuan pembelajaran bahasa Arab di IAIN Metro harus lebih diprioritaskan pada keterampilan membaca. Selain keterampilan membaca, pada jurusan KPI keterampilan bahasa yang juga harus dikuasai adalah keterampilan berbicara (maharah kalam) karena profil lulusan jurusan KPI diantaranya adalah sebagai Da'i (mubaligh), Public Relation, Penyuluh agama yang memang lebih menekankan kemampuan beretorika. 2) Menyusun kembali materi-materi ajar bahasa Arab. Materi-materi yang ditetapkan harus berupa materi yang mengasah keterampilan membaca bagi mahasiswa, pilihan tema bacannya yang disesuaikan dengan jurusan masing-masing. Misalnya pada mahasiswa jurusan Akhwalu Syajkhsyiah maka materi-materi berupa teks-teks berbahasa Arab dengan tema-tema hukum dan ketata negaraan, percakapan dan menghafal mufrodat yang berhubungan dengan hukum islam. Atau misalnya pada mahasiswa jurusan Ekonomi Syariah dengan profil lulusannya sebagai analis ekonomi syariah, praktisi lembaga keuangan dan ZISWAF, konsultan bisnis di lembaga keuangan syariah, dewan pengawas keuangan yariah, maka materi-materi bahasa arab yang harus diberikan adalah teks-teks bacaan tentang kegiatan-kegiatan di Bank, menghafal kosa kata seputar bank, BMT dan lain-lain. Begitu juga dengan jurusan yang lain tema-tema materinya dapat menyesuaikan. 


\section{Daftar Pustaka}

Ali, M. Sayuthi. Metodologi Penelitian Agama; Pendekatan Teori dan Praktek. Jakarta: PT RajaGrafindo Persada, 2002.

Arikunto, Suharsimi. Prosedur Penelitian Suatu Pendekatan Praktik. Bandung: Rineka Cipta, 1993.

Djiwandono, M. Soenardi. Tes Bahasa dalam Pengajaran. Bandung: ITB, 1996.

Koentjaraningrat, ed. Metode Penelitian Masyarakat. Jakarta: Gramedia, 1991.

Moleong, Lexy J. Metodologi Penelitian Kualitatif. Bandung: Remaja Karya, 1989.

Muhbib, Abdul Wahab. "Standarisasi Kompetensi Bahasa Arab bagi Calon Sarjana Keguruan Tinggi Keagamaan Islam Negeri.” Jurnal Arabiyat Vol. 5 No. 1, (Juni 2018). http://dx.doi.org/10.15408/a.v5i1.6691.

Mujawar, Muhammad Sholahuddin. Tadris Al Lughah Al Arabiyah bil Marhalah Al Ibtidaiyah. Kuwait: Dar Al Qolam, 1980.

Muradi, Ahmad. "Pengembangan Kompetensi Guru Bahasa Arab melalui IMLA sebagai Organisasi Profesi.” Jurnal Arabi Vol 1 No 2 (2016): 3-10.

Nata, Abuddin. Perspektif Islam tentang Strategi Pembelajaran. Jakarta: Kencana, 2009.

Rahmi, Novita. "Relevansi Kurikulum Dan Wujud Kongkret Tujuan Pembelajaran Bahasa Arab." An Nabighoh: Jurnal Pendidikan Dan Pembelajaran Bahasa Arab 19, no. 1 (30 Juli 2017): 107-26. https://doi.org/10.32332/an-nabighoh.v19i1.760.

Sulastri. "Pengembangan Media Pembelajaran Arabic Thematic Video Pada Keterampilan Berbicara Siswa Kelas VIII MTS.” Jurnal Lisanul Arab Vol 5 No 1 (2016).

Sutopo, Heribertus. Pengantar Penelitian Kualitatif: Dasar-Dasar Teoritis dan Praktis. Surakarta: Puslit UMS, 1988.

Tajuddin, Shafruddin. "Pengembangan Model Pembelajaran Bahasa Arab Tingkat Sekolah Dasar untuk Meningkatkan Kemampuan Berbahasa Arab Siswa." Parameter: Jurnal Pendidikan Universitas Negeri Jakarta 29, no. 2 (21 Juni 2017): 200-215. https://doi.org/10.21009/parameter.292.08.

Tim Dosen Administrasi Pendidikan UPI. Manajemen Pendidikan. Bandung: Alfabeta, 2009.

Tuhfah, Baiq. "Pembelajaran Bahasa Arab Melalui Pendekatan Komunikatif” Vol 4, No 1 (Juni 2016). 